\title{
Pembangunan Sistem Informasi Perpustakaan Fakultas Ilmu Sosial Universitas Negeri Jakarta
}

\author{
Adhitama Akbar'), Mira Ziveria ${ }^{2)}$ \\ Sistem Informasi, Fakultas Industri Kreatif Institut Teknologi dan Bisnis Kalbis \\ Jalan Pulomas Selatan kav.22, Jakarta Timur 13210 \\ ${ }^{1)}$ Email: adhitamaakbar@gmail.com \\ ${ }^{2)}$ Email: mira.ziveria@kalbis.ac.id
}

\begin{abstract}
As a reliable source of information on students, lecturers and campus community, Library of Faculty of Social Sciences, Jakarta State University must have a fast and precise process in service and data processing. Researchers design and build web-based information systems that can be used by librarians in running processes in the library, especially data processing and reports. System development is done with System Development Life Cycle (SDLC) Waterfall model. Then the system design is done by modeling language using Unified Modeling Language (UML). While the programming language used is PHP and HTML and database using MYSQL. The final result of the design is a webbased library information system for Library of Faculty of Social Sciences, Jakarta State University with librarians as users of the system that can process library data and reports. System testing is done by Black Box testing by the system user (librarian), the result of the test can be concluded that the system has been as expected.
\end{abstract}

Keywords: Black Box, information system, library, UML, Waterfall, web

\begin{abstract}
Asbtrak: Sebagai sumber informasi yang diandalkan mahasiswa, dosen dan masyarakat kampus, Perpustakaan Fakultas Ilmu Sosial Universitas Negeri Jakarta harus mempunyai proses yang cepat dan tepat dalam layanan maupun pengolahan datanya. Peneliti merancang dan membangun sistem informasi berbasis web yang dapat digunakan oleh pustakawan dalam menjalankan proses-proses di dalam perpustakaan khususnya pengolahan data dan laporan. Pengembangan sistem dilakukan dengan System Development Life Cycle (SDLC) model Waterfall. Kemudian perancangan sistem dilakukan dengan bahasa pemodelan menggunakan Unified Modelling Language (UML). Sedangkan bahasa pemograman yang dipakai adalah PHP dan HTML serta basis data menggunakan MySQL. Hasil akhir perancangan tersebut menghasilkan sistem informasi perpustakaan berbasis web untuk Perpustakaan Fakultas Ilmu Sosial Universitas Negeri Jakarta dengan pustakawan sebagai pengguna sistem yang dapat mengolah data dan laporan perpustakaan. Pengujian sistem dilakukan dengan pengujian Black Box oleh pengguna sistem yaitu pustakawan, hasil dari pengujian tersebut dapat disimpulkan bahwa sistem telah sesuai dengan yang diharapkan.
\end{abstract}

Kata kunci: Black Box, perpustakaan, sistem informasi, UML, Waterfall, web

\section{PENDAHULUAN}

Perkembangan teknologi informasi dan komputer saat ini semakin berkembang pesat, dengan keberadaan komputer, kelancaran dan kebutuhan dalam memperoleh informasi yang akurat akan lebih cepat diproses. Komputer merupakan alat pengolah data dengan kemampuan yang lebih baik dibandingkan dengan manusia dalam beberapa aspek. Diantaranya dalam hal kecepatan, keakuratan dan efisiensi. Komputer banyak digunakan oleh manusia untuk melakukan berbagai analisa pengambilan keputusan.
Maka dari itu, sistem komputerisasi dapat digunakan untuk membantu dalam memberikan pelayanan yang cepat dan tepat. Keterlibatan teknologi komputer sudah banyak dipakai dalam melakukan proses-proses bisnis di dalam perusahaan atau organisasi. Misalnya seperti lembaga-lembaga pendidikan yang memiliki salah satu penunjang kegiatan dalam mengakses informasi buku yaitu perpustakaan.

Perpustakaan berperan penting dalam memajukan lembaga pendidikan karena perpustakaan merupakan tempat untuk meningkatkan ilmu pengetahuan bagi para guru, para siswa maupun para 
pendidik. Kemudahan, kecepatan dan keakuratan untuk memperoleh informasi yang dibutuhkanmenjadi nilai tambah bagi perpustakaan untuk memberikan pelayanan bagi anggota perpustakaan sekaligus menyiapkan Sumber Daya Manusia yang bermutu di masa depan. Perpustakaan berkembang dengan pesat dan dinamis, khususnya kegiatan rutin dalam bidang pengadaan, pencatatan, serta pengawasan sirkulasi buku dan anggota perpustakaan. Keadaan demikian menuntut penggunaan sistem informasi berbasis teknologi komputer.

Perpustakaan Fakultas Ilmu Sosial (FIS) Universitas Negeri Jakarta (UNJ) adalah salah satu sumber informasi yang diandalkan oleh para dosen, mahasiswa maupun orang-orang disekitar lingkungan UNJ. Perpustakaan FIS UNJ bertujuan untuk menyediakan akses informasi yang mendukung civitas UNJ khususnya FIS dalam proses belajarmengajar, penelitian, serta pengabdian masyarakat. Sebagai sumber informasi yang diandalkan, perpustakaan tersebut harus mempunyai proses yang cepat dan tepat dalam layanan maupun pengolahan datanya. Namun, dalam hal pengaksesan data di perpustakaan tersebut masih menggunakan cara lama yaitu memakai software Microsoft Office Excel. Microsoft Office Excel digunakan perpustakaan tersebut untuk melakukan berbagai proses pengolahan data seperti, pengolahan data buku, data peminjaman buku, serta data anggota. Oleh karena itu, data yang tersimpan di dalam file Excel tersebut sangat banyak karena petugas hanya menggunakan satu file untuk semua kegiatan di perpustakaan. Kondisi seperti itu sangat beresiko karena jika petugas kehilangan file tersebut, maka semua datanya akan hilang. Selain itu, kelambatan mengakses data yang diakibatkan oleh data yang menumpuk dalam satu file. Masalah lain yang ditemukan yaitu perpustakaan ini tidak memiliki katalog buku, sehingga pengunjung yang datang tidak bisa menanyakan buku yang tersedia kepada pustakawan melainkan mencari sendiri pada rak-rak buku yang tersedia.

Dari latar belakang di tersebut, peneliti akan merancang dan membangun sistem informasi berbasis web yang diharapkan dapat memberi kemudahan kepada petugas perpustakaan dalam menginput data dan mengolah laporan. Sistem informasi berbasis web ini juga akan memudahkan civitas kampus bahkan masyarakat di luar kampus dalam mengakses informasi buku yang ada di dalam Perpustakaan FIS UNJ melalui fitur pencarian katalog buku yang akan peneliti buat. Berdasarkan uraian latar belakang masalah, maka dapat dirumuskan permasalahan yaitu bagaimana merancang dan membangun sistem informasi Perpustakaan Fakultas Ilmu Sosial Universitas Negeri Jakarta berbasis web? Tujuan penelitian ini adalah untuk merancang dan membangun sistem informasi perpustakaan berbasis web pada Perpustakaan Fakultas Ilmu Sosial Universitas Negeri Jakarta.

\section{METODE PENELITIAN}

\section{A. Sistem Informasi Perpustakaan}

Berikut adalah penjelasan dari sistem informasi, perpustakaan dan sistem informasi perpustakaan.

1. Sistem Informasi. Sistem Informasi adalah suatu sistem di dalam suatu organisasi yang mempertemukan kebutuhan pengolahan transaksi harian yang mendukung fungsi operasi organisasi yang bersifat manajerial dengan kegiatan strategi dari suatu organisasi untuk dapat menyediakan kepada pihak luar tertentu dengan laporan-laporan yang diperlukan [1]. Sistem informasi adalah suatu komponen yang terdiri dari manusia, teknologi informasi, dan prosedur kerja yang memproses, menyimpan, menganalisis, dan menyebarkan informasi untuk mencapai suatu tujuan [2].

2. Perpustakaan. Kata perpustakaan berasal dari kata pustaka, yang berarti: (1) kitab, buku-buku, (2) kitab primbon. Kemudian kata pustaka mendapat awalan per dan akhiran an, menjadi perpustakaan. Perpustakaan mengandung arti: (1) kumpulan bukubuku bacaan, (2) bibliotek, dan (3) buku-buku kesusasteraan (Kamus Besar Bahasa Indonesia$\mathrm{KBBI}$ ). Selanjutnya ada pula istilah pustaka loka yang berarti tempat atau ruangan perpustakaan. Pengertian yang lebih umum dan luas tentang perpustakaan yaitu mencakup suatu ruangan, bagian dari gedung / bangunan, atau gedung tersendiri, yang berisi bukubuku koleksi, yang disusun dan diatur demikian rupa, sehingga mudah untuk dicari dan dipergunakan apabila sewaktu-waktu diperlukan oleh pembaca. Perpustakaan dilengkapi dengan berbagai sarana dan prasarana, seperti ruang baca, rak buku, rak majalah, meja-kursi baca kartu-kartu katalog, sistem pengelolaan tertentu, dan ditempatkan karyawan atau petugas yang melaksanakan kegiatan perpustakaan agar semuanya berjalan sebagaimana mestinya [3].

3. Sistem Informasi Perpustakaan. Sistem informasi perpustakaan adalah suatu sistem terkomputerisasi yang digunakan di perpustakaan untuk memudahkan dalam menjalankan proses sirkulasi dalam perpustakaan seperti pendataan peminjaman dan pengembalian buku maupun 
laporan-laporan lain yang diperlukan [4]. Sistem informasi perpustakaan dapat juga diartikan sebagai automasi perpustakaan dalam lingkup pengolahan informasi.

\section{B. Website}

Website atau situs web adalah kumpulan halaman yang menampilkan informasi berupa teks, gambar, suara, video atau gabungan dari semuanya membentuk suatu rangkaian kemudian terhubung dengan jaringan-jaringan halaman lainnya dengan menggunakan internet. Website terbagi menjadi dua jenis yaitu statis dan dinamis. Website statis yaitu situs yang menampilkan informasi tetap, jarang berubah, dan isi informasinya berasal dari pemilik situs itu sendiri. Sedangkan website dinamis yaitu situs yang menampilkan informasi berubah-ubah dan isinya berasal dari pemilik maupun pengguna situs tersebut. Untuk membangun suatu website diperlukan bahasa pemrograman. Ada beberapa bahasa pemrograman untuk membangun website diantaranya yaitu HTML dan PHP. HTML adalah file teks murni yang dapat dibuat dengan editor text apapun. File HTML ini berisi instruksi-instruksi yang kemudian diterjemahkan oleh browser yang ada di komputer pengguna sehingga isi dari HTML tersebut dapat ditampilkan secara visual di komputer pengguna [5].

\section{Database}

Database atau Basis data adalah kumpulan data yang saling berelasi. Basis data juga merupakan himpunan kelompok data yang saling berhubungan yang diorganisasi sedemikian rupa tanpa pengulangan (redundansi) yang tidak perlu sehingga kelak dapat dimanfaatkan untuk memenuhi kebutuhan dengan cepat dan mudah. Basis data bertujuan untuk mengatur data sehingga diperoleh kemudahan, ketepatan dan kecepatan dalam pengambilan data kembali [6].

\section{XАMPP}

XAMPP adalah perangkat lunak bebas, yang mendukung banyak sistem operasi dan merupakan kompilasi dari beberapa program. Fungsinya adalah sebagai server yang berdiri sendiri (localhost), yang terdiri atas program Apache HTTP Server, MySQL database, dan penerjemah bahasa yang ditulis dengan bahasa pemrograman PHP dan Perl. Nama XAMPP merupakan singkatan dari $\mathrm{X}$ (empat sistem operasi apapun), Apache, MySQL, PHP dan Perl. Program ini tersedia dalam GNU dan bebas, merupakan web server yang mudah digunakan yang dapat melayani tampilan halaman web yang dinamis [7].

\section{E. Pemodelan Sistem}

Pemodelan sistem adalah perancangan dari sebuah sistem yang akan dibuat dengan menggunakan model/diagram untuk menggambarkannya. Berikut adalah beberapa jenis pemodelan sistem.

\section{Unified Modelling Language}

Unified Modelling Language (UML) merupakan bahasa visual untuk pemodelan dan komunikasi mengenai sebuah sistem dengan menggunakan diagram dan teks-teks pendukung [8].

\section{a. Use Case Diagram}

Use case atau diagram use case merupakan pemodelan untuk kelakuan (behavior) sistem informasi yang akan dibuat. Use case mendeskripsikan sebuah interaksi antara satu atau lebih aktor dengan sistem informasi yang akan dibuat. Secara kasar, use case digunakan untuk mengetahui fungsi apa saja yang ada di dalam sebuah sistem informasi dan siapa saja yang berhak menggunakan fungsi-fungsi itu [8]. b. Activity Diagram

Diagram aktivitas atau activity diagram menggambarkan workflow (aliran kerja) atau aktivitas dari sebuah sistem atau proses bisnis atau menu yang ada pada perangkat lunak. Yang perlu diperhatikan disini adalah bahwa diagram aktivitas menggambarkan aktivitas sistem bukan apa yang dilakukan aktor, jadi aktivitas yang dapat dilakukan oleh sistem [8].

\section{c. Class Diagram}

Diagram kelas atau class diagram menggambarkan struktur sistem dari segi pendefinisian kelas-kelas yang akan dibuat untuk membangun sistem. Kelas memiliki apa yang disebut atribut dan metode atau operasi. Diagram kelas dibuat agar pembuat program atau programmer membuat kelas-kelas sesuai rancangan di dalam diagram kelas agar antara dokumentasi perancangan dan perangkat lunak sinkron [8].

\section{Entity Relationship Diagram}

Entity Relationship Diagram (ERD) adalah suatu rancangan atau bentuk hubungan suatu kegiatan di dalam sistem yang berkaitan langsung dan mempunyai fungsi dalam proses tersebut [9].

\section{Cross Functional Flowchart}

Cross Functional Flowchart atau disebut juga Swimlane Flowchart adalah diagram yang menggambarkan aktivitas dari setiap stakeholder yang terlibat di dalam kegiatan bisnis perusahaan; 
diagram ini merepresentasikan flow proses yang menggambarkan interaksi dari beberapa bagian yang berbeda dan bagaimana perkembangan proses melalui beberapa phase yang berbeda. [10].

\section{F. Black Box Testing}

Black Box Testing merupakan pengujian yang berfokus pada spesifikasi fungsional dari perangkat lunak, tester dapat mendefinisikan kumpulan kondisi input dan melakukan pengetesan pada spesifikasi fungsional program. Black Box Testing dilakukan untuk memastikan output aplikasi berjalan dengan benar untuk semua jenis masukan positif dan negatif. Ada berbagai jenis Black Box Testing seperti Equivalence Class Partitioning, Boundary Value Analysis, Error Guessing, d11 [11].

\section{G. System Development Life Cycle}

System Development Life Cycle (SDLC) merupakan metodologi klasik yang digunakan untuk mengembangkan, memelihara, dan menggunakan sistem informasi [12].

\section{Waterfall}

Model SDLC Waterfall merupakan metode dalam mengerjakan pengembangan software dimana setiap fase harus dikerjakan dulu sebelum fase berikutnya dijalankan [13]. Berikut ini adalah tahaptahap dari SDLC model Waterfall.

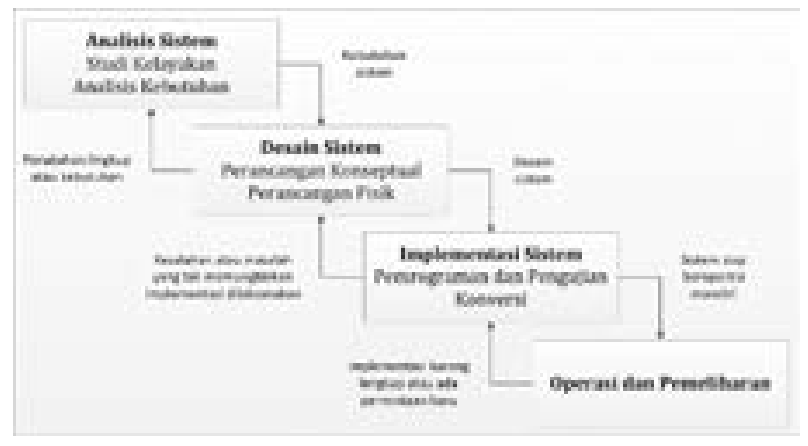

Gambar 1 Tahapan SDLC model Waterfall

a. Analisis Sistem. Peneliti menganalisis sistem yang sedang berjalan dan menentukan masalah apa yang terjadi pada sistem berjalan tersebut. Selain itu juga menganalisis apa kebutuhan dari sistem yang berjalan.

b. Desain Sistem. Peneliti merancang konsep sistem yang akan dibuat sesuai dengan analisis kebutuhan sistem yang didapat. Jika ada perubahan lingkup atau kebutuhan, maka akan kembali ke tahap analisis untuk kembali dianalisis.

c. Implementasi Sistem. Pada tahap ini peneliti melakukan pengkodean sistem informasi yang sudah di rancang. Kemudian program tersebut diuji oleh pihak yang diteliti. Jika ada kesalahan atau masalah yang memungkinkan untuk tidak diimplementasikan maka akan kembali ke tahap desain untuk menganalisis masalah yang terjadi.

d. Operasi dan Pemeliharaan. Tahap ini adalah untuk pengimplementasian sistem informasi yang sudah dibuat serta pemeliharaan sistem yang dilakukan secara rutin. Jika implementasi kurang lengkap atau ada permintaan baru maka dapat kembali ke tahap sebelumnya.

\section{H. Metodologi Penelitian}

Metodologi penelitian berhubungan dengan prosedur, alat serta desain penelitian yang digunakan dalam melaksanaan penelitian. Penelitian ini dilakukan melalui beberapa tahapan sesuai dengan tahapan System Development Life Cycle (SDLC) model waterfall. Tahapan proses dalam penelitian ini mengalir sesuai dengan alur yang logis. Tujuannya adalah memberikan petunjuk yang jelas, teratur dan sistematis. Tahapan penelitian ini dapat dilihat pada Gambar 2.

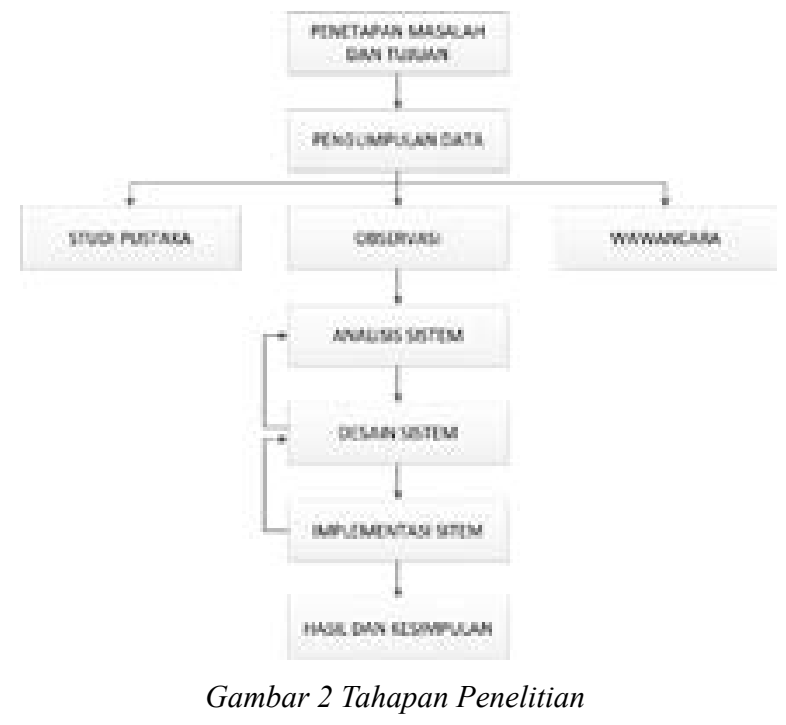

1. Penetapan Masalah dan Tujuan

Menetapkan lokasi dan permasalahan yang terjadi serta tujuan pada awal penelitian.

2. Pengumpulan Data. Melakukan pengumpulan data yang dibutuhkan dalan penelitian dengan beberapa cara, yaitu: a) Studi Pustaka. Teknik pengumpulan data yang dilakukan dengan mempelajari bukubuku referensi, laporan-laporan, majalah-majalah, jurnal-jurnal dan media lainnya yang berkaitan dengan obyek penelitian; b) Observasi. Observasi yang dilakukan oleh peneliti berupa pengamatan dan catatan langsung terhadap obyek penelitian, yaitu mengamati proses sirkulasi pada Perpustakaan 
Fakultas Ilmu Sosial Universitas Negeri Jakarta; dan c) Wawancara. Wawancara adalah percakapan yang dilakukan oleh dua pihak yaitu pewawancara yang mengajukan pertanyaan dan informan yang memberikan jawaban atas pertanyaan. Melalui wawancara ini pula peneliti menggali informasi secara mendalam dari narasumber mengenai masalah yang sering dihadapi dan kebutuhan dalam menjalankan proses pada Perpustakaan Fakultas Ilmu Sosial Universitas Negeri Jakarta

3. Analisis Sistem. Pada tahap ini peneliti menganalisis sistem yang sedang berjalan pada lokasi penelitian dan menganalisis kebutuhan sistemnya.

4. Desain Sistem. Tahap selanjutnya mendesain sistem dalam bentuk perancangan menggunakan beberapa model diagram sesuai dengan analisis kebutuhan yang telah dilakukan. Jika dalam perancangan ada kesalahan, maka dapat kembali ke tahap sebelumnya yaitu analisis sistem untuk menganalisis kembali dimana letak kesalahan yang terjadi.

5. Implementasi Sistem. Tahap ini merupakan tahap pengkodean sistem mulai dari pembuatan database sampai dengan penulisan skrip PHP sesuai dengan rancangan yang dibuat. Jika pada pengkodean terjadi masalah atau ada penambahan fitur, maka dapat kembali ke tahap perancangan sistem. Setelah selesai pengkodean sistem, peneliti melakukan uji coba sistem informasi yang sudah dibuat pada lokasi penelitian dan akan diuji oleh pihak Perpustakaan FIS UNJ. Jika terjadi kesalahan atau adanya kekurangan pada sistem, maka kembali ke tahap pengkodean untuk menyelesaikan masalah yang terjadi.

6. Hasil dan Kesimpulan. Setelah lolos dari tahap uji coba, maka penelitimelakukan implementasi sistem informasi dan menulis hasil laporan penelitian. Pada penelitian ini, peneliti tidak melanjutkan tahap sampai operasi dan pemeliharaan seperti pada Gambar 1 karena tahap tersebut dilakukan oleh pihak Perpustakaan FIS UNJ.

\section{HASIL DAN PEMBAHASAN}

\section{A. Analisis Sistem}

Pada tahap ini peneliti menganalisis sistem yang sedang berjalan pada lokasi penelitian dan menganalisis kebutuhan sistemnya.

\section{Analisis Sistem Berjalan}

Berikut adalah sistem yang berjalan saat ini di Perpustakaan Fakultas Ilmu Sosial (FIS) Universitas
Negeri Jakarta (UNJ) yang ditunjukkan dengan flowchart pada Gambar 3 dan Gambar 4.

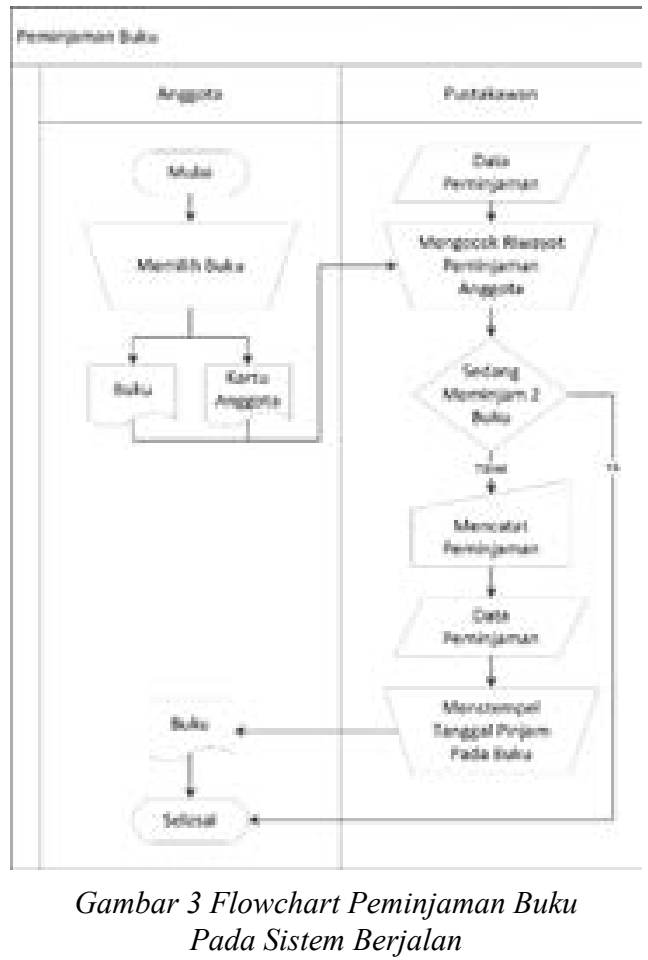

Gambar 3 menjelaskan proses peminjaman buku pada sistem yang berjalan, yaitu, Anggota memilih buku yang akan dipinjam kemudian memberikan buku dan kartu anggota kepada Pustakawan, lalu Pustakawan mengecek riwayat peminjaman Anggota apakah sedang meminjam 2 buku atau tidak, karena maksimal peminjaman setiap Anggota adalah 2 buku. Setelah itu, Pustakawan mencatat data peminjaman di Excel dan memberikan stempel tanggal pinjam pada

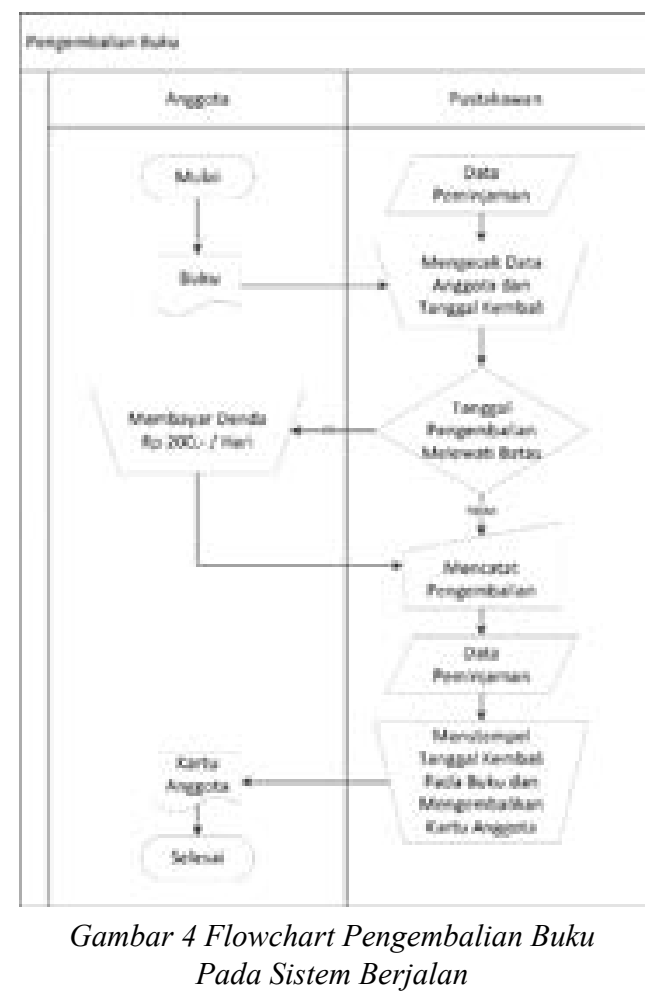


buku yang dipinjam. Peminjaman diberikan waktu 1 minggu (7 hari). Kartu Anggota disimpan oleh Pustakawan sebagai jaminan peminjaman. Kemudian Anggota menerima buku.

Prosespengembalianbukuyangditunjukkanpada Gambar 4 yaitu, Anggota memberikan kembali buku yang dipinjam kepada Pustakawan, lalu Pustakawan mengecek data Anggota dan tanggal pengembalian yang ditentukan, jika tanggal pengembalian melewati tanggal yang ditentukan maka Anggota dikenakan denda Rp 200 per hari. Setelah itu, Pustakawan mencatat data pengembalian dan menstempel tanggal kembali pada buku, kemudian mengembalikan kartu anggota kepada Anggota. Pengunjung yang bukan Anggota tidak dapat meminjam buku dan tidak ada pendaftaran Anggota baru untuk Pengunjung yang bukan dari Fakultas Ilmu Sosial, tetapi Pengunjung masih bisa membaca buku didalam perpustakaan.

\section{Analisis Kebutuhan}

Dalam tahap ini dilakukan dua jenis analisis kebutuhan yang diperlukan dalam membangun sistem informasi, yaitu analisis kebutuhan fungsional dan analisis kebutuhan non-fungsional. Kebutuhan fungsional adalah jenis kebutuhan yang berisikan proses-proses/fitur-fitur apa saja yang diberikan oleh sistem informasi kepada pengguna. Sistem informasi ini dapat digunakan oleh beberapa pengguna yaitu Pustakawan, Pengunjung, dan Anggota. Pada Tabel 1 berikut adalah kebutuhan fungsional dari sistem informasi yang dibuat.

Tabel 1 Kebutuhan Fungsional

\begin{tabular}{ll}
\hline User & Kebutuhan \\
\hline Pustakawan & 1. Melakukan login \\
& 2. Mengolah data anggota \\
& 3. Mengolah data pengunjung \\
& 4. Mengolah data buku \\
& 5. Mengolah data peminjaman buku \\
& 6. Mengolah data pengembalian buku \\
& 7. Mencari buku pada katalog buku \\
& 8. Melakukan logout \\
\hline Pengunjung & 1. Mencari buku pada katalog buku \\
\hline Anggota & 1. Mencari buku pada katalog buku \\
\hline
\end{tabular}

Analisis kebutuhan non-fungsional dilakukan untuk mengetahui spesifikasi kebutuhan untuk sistem. Spesifikasi kebutuhan melibatkan analisis perangkat keras (hardware), dan analisis perangkat lunak (software).

\section{B. Desain Sistem}

Tahap selanjutnya mendesain sistem dalam bentuk perancangan menggunakan beberapa model diagram sesuai dengan analisis kebutuhan yang telah dilakukan. Perancangan ini terdiri dari perancangan sistem, perancangan basis data dan perancangan antarmuka. Berikut adalah perancangan-perancangan yang sudah dibuat oleh peneliti.

\section{Perancangan Sistem}

Perancangan sistem yang dibuat oleh peneliti menggunakan Unified Modelling Language (UML) yaitu Use Case Diagram dan Activity Diagram.

\section{a. Use Case Diagram}

Pada sistem informasi Perpustakaan Fakultas Ilmu Sosial (FIS) Universitas Negeri Jakarta (UNJ) terdiri dari beberapa proses yaitu, login, pengelolaan anggota, pendaftaran anggota, penerimaan pengunjung, pencarian katalog buku, peminjaman buku, pengembalian buku, dan pengolahan buku. Proses-proses tersebut dilakukan oleh aktor-aktor yaitu, Pustakawan, Anggota, dan Pengunjung seperti yang ditunjukkan pada Gambar 5.

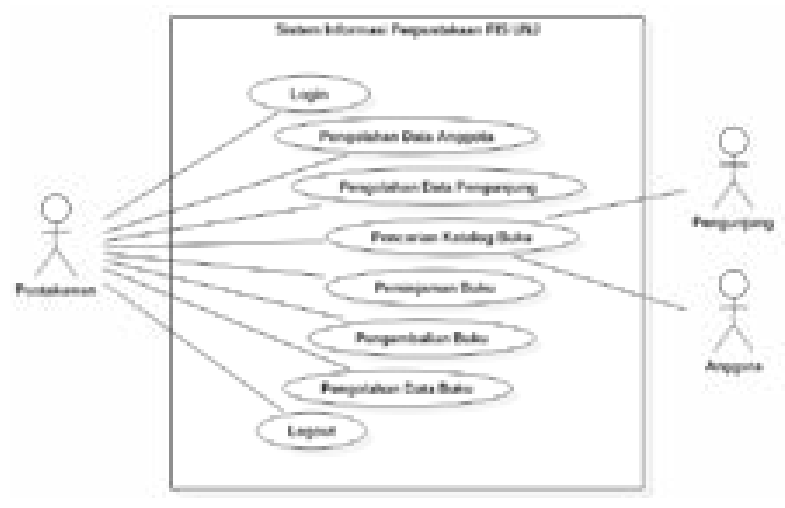

Gambar 5 Use Case Diagram

Pustakawan sebagai aktor utama yang menjalankan seluruh proses mulai dari login, pengelolaan anggota, pendaftaran anggota, penerimaan pengunjung, pencarian katalog buku, peminjaman buku, pengembalian buku, dan pengolahan buku. Proses pencarian katalog buku dapat dilakukan oleh semua aktor karena Pustakawan, Anggota, dan Pengunjung dapat melakukan pencarian buku pada sistem.

\section{b. Activity Diagram}

Activity diagram adalah alur kegiatan sistem yang dirancang berdasarkan use case yang telah dibuat. Penggambaran activity diagram dibuat berdasarkan aktor yang terlibat di dalam sistem yaitu, pustakawan, anggota, dan pengunjung.

Gambar 6 merupakan activity diagram yang menggambarkan proses semua aktor melakukan pencarian katalog buku. Aktor-aktor tersebut yaitu pustakawan, anggota, dan pengunjung. Aktor-aktor tersebut dapat menggunakan sistem untuk pencarian katalog buku tanpa harus login karena fitur pencarian katalog buku berada di halaman awal ketika 


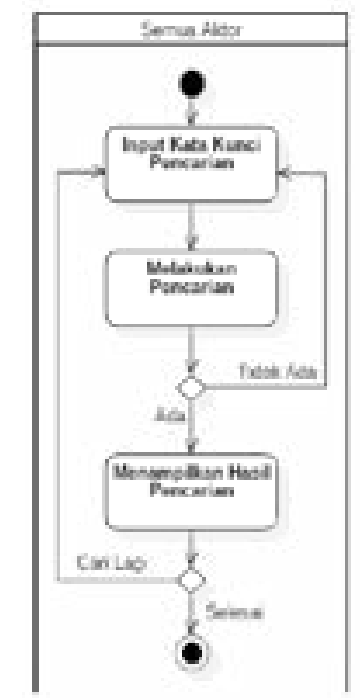

Gambar 6 Activity Diagram Pencarian Katalog Buku

membuka sistem. Kemudian aktor memasukkan kata kunci pencarian pada kolom teks yang disediakan. Sistem akan melakukan pencarian dan menampilkan hasil pencarian berupa list buku. Setelah melihat hasil pencarian, aktor dapat melakukan pencarian kembali atau selesai.

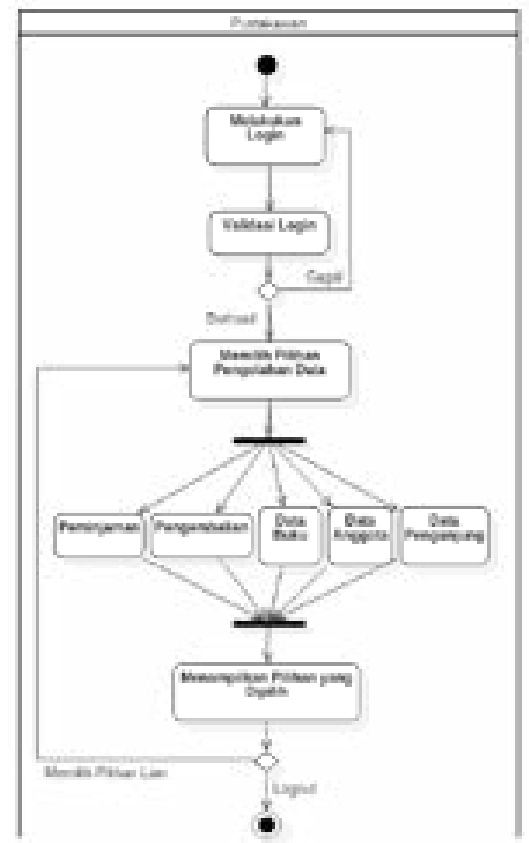

Gambar 7 Activity Diagram Login

Gambar 7 menggambarkan activity diagram pada proses login. Proses ini hanya dilakukan oleh pustakawan. Pustakawan melakukan login dengan memasukkan username dan password. Lalu sistem melakukan validasi login, jika login gagal berarti ada kesalahan yang berarti username dan password tidak cocok, maka sistem memberi output warning gagal login dan pustakawan kembali memasukkan username dan password yang benar. Jika login berhasil, maka sistem menampilkan pilihan pengolahan data yang berisi peminjaman, pengembalian, data buku, data anggota, dan data pengunjung. Kemudian menampilkan pilihan yang telah dipilih, dan dapat memilih pilihan lain atau logout.

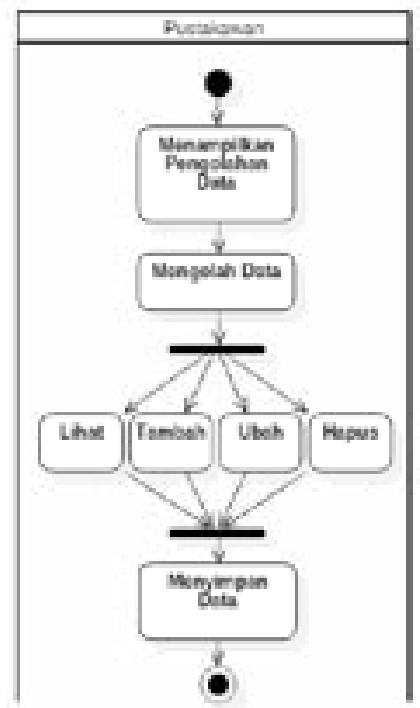

Gambar 8 Activity Diagram Pengolahan Data

Activity diagram pengolahan data seperti yang digambarkan pada Gambar 8 menjelaskan proses pengolahan data seperti data buku, data anggota, dan data pengunjung. Prosesnya dilakukan setelah melakukan login, kemudian sistem menampilkan pengolahan data. Pustakawan dapat mengolah data dengan beberapa pilihan yaitu lihat, tambah, ubah, dan hapus. Pilihan pertama, lihat, yaitu melihat data secara detail. Kedua, pilihan tambah, adalah proses menambah data baru. Pilihan ketiga yaitu ubah, adalah proses mengubah data yang sudah ada. Pilihan yang keempat yaitu hapus, adalah proses menghapus data dari tabel. Kemudian sistem menyimpan data setelah pustakawan melakukan pilihan mengolah data.

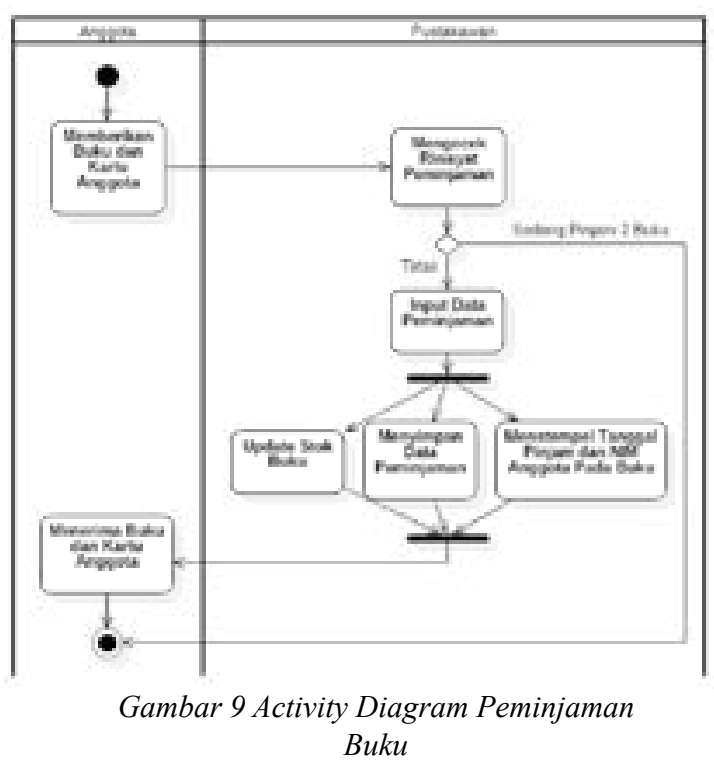


Pada Gambar 9 menjelaskan activity diagram dari proses peminjaman buku oleh pustakawan. Anggota yang ingin meminjam buku memberikan buku yang ingin dipinjam dan kartu anggota kepada pustakawan. Setelah itu, pustakawan menginput NIM anggota untuk mencari riwayat peminjaman anggota tersebut. Kemudian sistem mengecek riwayat peminjaman anggota apakah sedang meminjam 2 buku atau tidak, karena batas peminjaman maksimal adalah 2 buku. Jika anggota sedang meminjam 2 buku, maka proses peminjaman selesai. Anggota tidak boleh meminjam buku sebelum mengembalikan buku yang sudah dipinjam. Jika tidak sedang meminjam 2 buku, maka proses berlanjut ke penginputan data peminjaman oleh pustakawan. Setelah itu, sistem meng-update stok buku pada data buku yang dipinjam, yaitu stok menjadi berkurang. Kemudian sistem menyimpan data peminjaman ke dalam data peminjaman. Lalu pustakawan menstempel tanggal pinjam dan NIM anggota pada buku sebelum diberikan kepada anggota. Setelah itu, anggota menerima buku dan kartu anggota kembali.

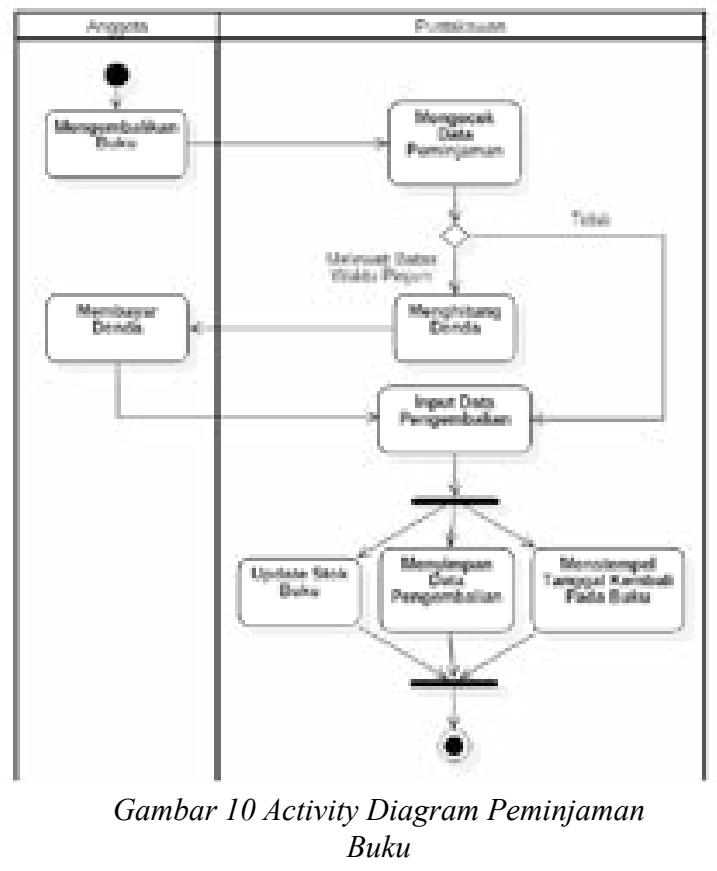

Activity diagram pada Gambar 10 menggambarkan proses pustakawan melakukan proses pengembalian buku. Anggota yang ingin mengembalikan buku, memberikan buku kepada pustakawan. Kemudian pustakawan menginput NIM anggota pada kolom pencarian untuk mengecek data peminjaman, lalu sistem menampilkan form kembali pengembalian. Pada form pengembalian, sistem menghitung lama pinjam apakah lebih dari 7 hari atau tidak. Jika lama pinjam tidak lebih dari 7 hari, maka sistem menampilkan denda Rp 0 dan proses lanjut ke penginputan data peminjaman. Jika lama pinjam lebih dari 7 hari maka sistem menghitung denda yang harus dibayar anggota (peminjam) dengan cara lama pinjam dikurang 7 hari lalu dikalikan Rp 200, hasilnya adalah nominal yang harus dibayar anggota (peminjam). Jika pustakawan sudah menerima pembayaran denda, maka proses berlanjut ke penginputan data peminjaman. Setelah itu, sistem meng-update kembali stok buku menjadi bertambah. Lalu sistem menyimpan data peminjaman dan menstempel tanggal kembali pada buku yang dikembalikan.

\section{Perancangan Basis Data}

Peneliti membagi perancangan basis data menjadi tiga bagian yaitu Level Konsep, Level Logic, dan Level Fisik.

\section{a. Level Konsep}

Perancangan basis data pada level konsep adalah perancangan yang menggambarkan interaksi dan relasi antar entitas dalam sistem dengan menggunakan Entity Relationship Diagram (ERD), berikut adalah penggambaran ERD pada Gambar 11.

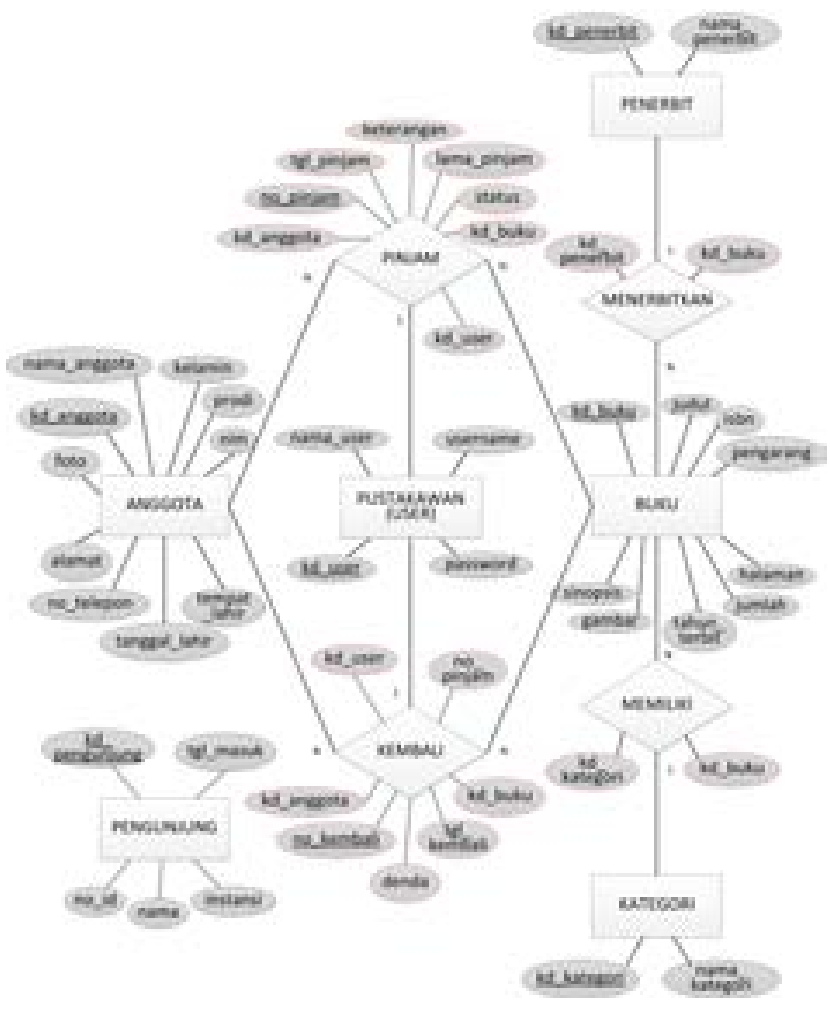

Gambar 11 Entity Relationship Diagram

\section{b. Level Logic}

Adapun perancangan basis data pada level logic yang digambarkan dengan class diagram seperti pada Gambar 12. Class diagram menunjukkan relasirelasi antar tabel yang merupakan turunan dari Entity Relationship Diagram (ERD) yang sebelumnya sudah dibuat. 


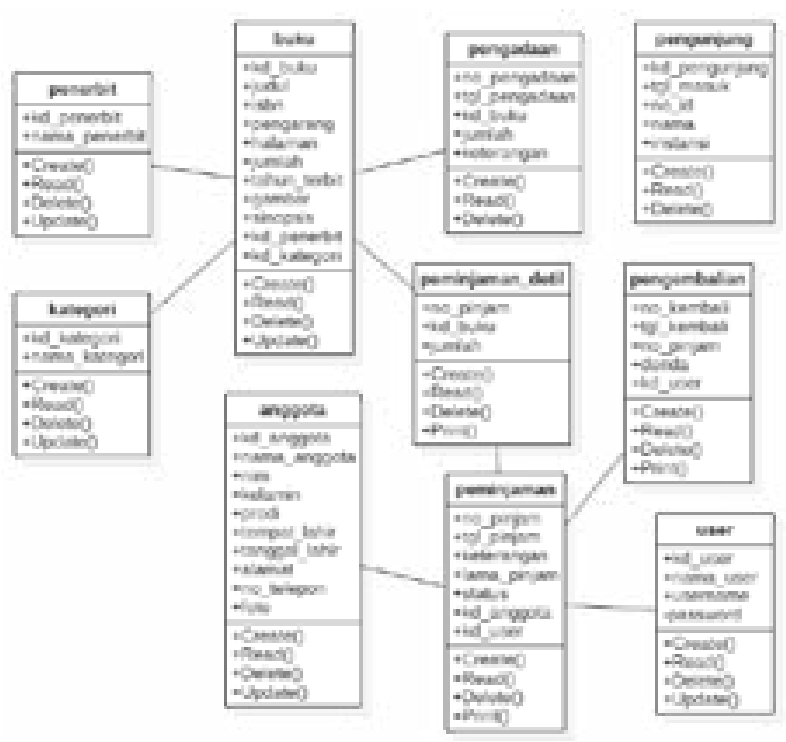

Gambar 12 Class Diagram

\section{c. Level Fisik}

Pada perancangan basis data di level fisik, peneliti menjelaskan struktur tabel yang dibuat pada basis data sesuai rancangan yang telah buat. Struktur tabel meliputi nama tabel, nama field (kolom), dan tipe data serta primary key (*) dan foreign key

\section{Perancangan Antarmuka}

Perancangan antarmuka adalah perancangan tampilan user interface dari sistem yang dibuat oleh peneliti.

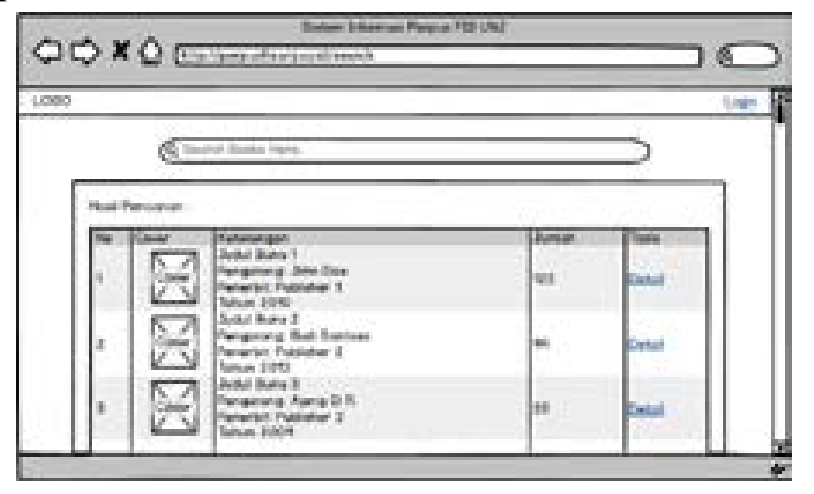

Gambar 13 Perancangan Halaman Pencarian Katalog Buku

Gambar 13 merupakan perancangan halaman pencarian atau halaman awal, yaitu halaman yang

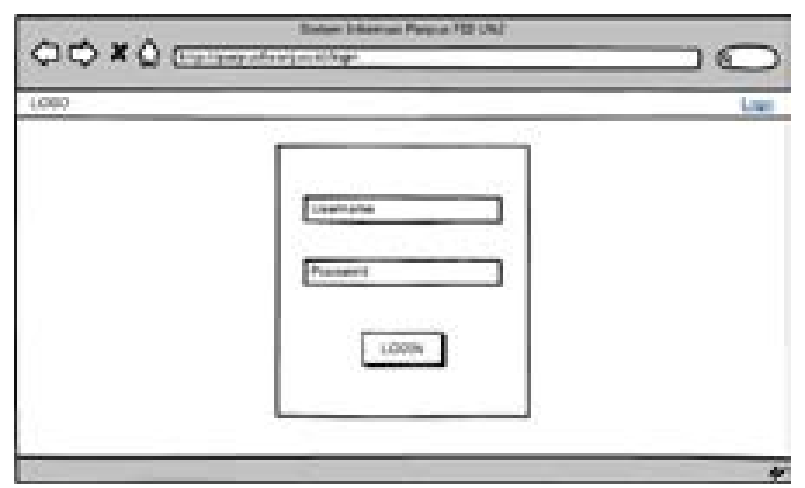

Gambar 14 Perancangan Halaman Login tampil pertama kali ketika membuka website Perpustakaan Fakultas Ilmu Sosial (FIS) Universitas Negeri Jakarta (UNJ). Pada halaman ini terdapat halaman pencarian untuk katalog buku yang dapat diakses oleh mahasiswa, anggota, pengunjung atau orang lain yang membuka website.

Gambar 14 merupakan perancangan halaman login, yaitu halaman yang tampil setelah meng-klik tombol "Login" pada pojok kanan atas halaman. Halaman login ini dikhususkan untuk user sekaligus admin sistem yaitu pustakawan.

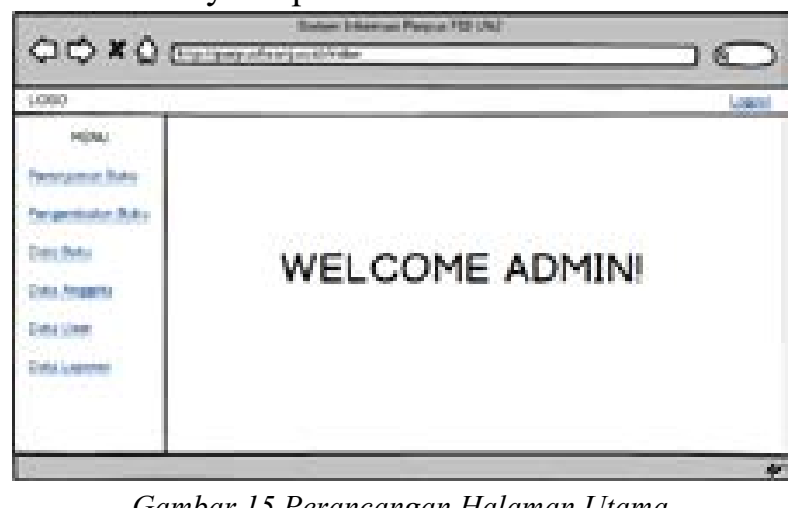

Gambar 15 Perancangan Halaman Utama

Pada Gambar 15 menampilkan halaman utama untuk pustakawan setelah melakukan login ke dalam sistem. Pada bagian atas halaman terdapat LOGO yang memiliki link, jika di klik akan ke halaman utama dan tombol "Logout" untuk melakukan logout dari sistem. Lalu pada bagian kiri halaman terdapat daftar menu navigasi untuk mengolah data, yang terdiri dari menu peminjaman buku, pengembalian buku, data buku, data anggota, data user, dan data laporan. Menu navigasi pada bagian atas dan kanan halaman ini akan ada di setiap tampilan halaman dalam sistem. Kemudian pada bagian isi halaman terdapat tulisan “WELCOME ADMIN!" yang diperuntukkan kepada pustakawan sebagai pesan selamat datang.

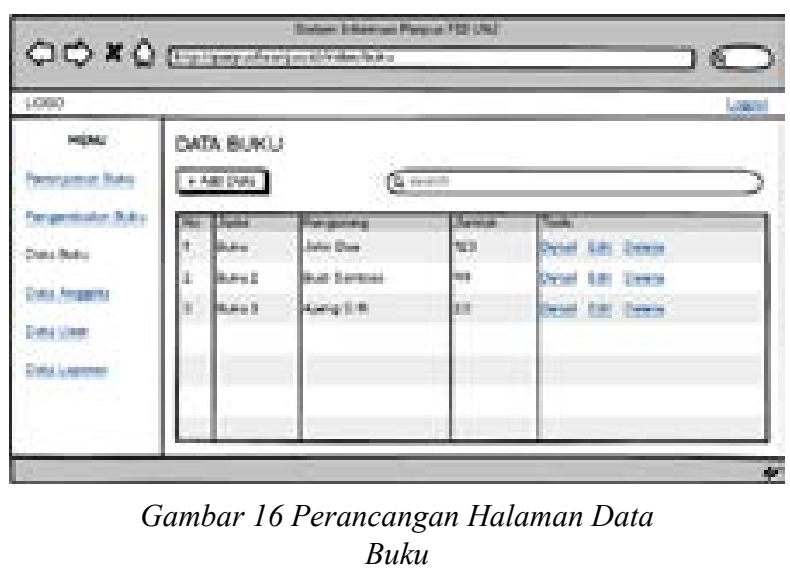

Gambar 16 merupakan perancangan halaman data buku, yaitu halaman yang tampil ketika memilih menu "Data Buku". Halaman ini menampilkan data buku yang terdaftar dalam database. Pada Gambar 
16 menggambarkan perancangan halaman data buku yang menampilkan tabel data buku dari database. Pada bagian isi halaman terdapat nama halaman yaitu "DATA BUKU", kemudian tombol "+Add Data" untuk opsi menambah data buku, kolom teks pencarian untuk mencari data buku, dan tabel data buku yang berisi nomor, judul buku, pengarang, jumlah stok, dan beberapa tools yaitu "Detail" untuk melihat detail buku seperti yang ditunjukkan pada Gambar 17, "Edit" untuk mengubah data buku, dan "Delete" untuk menghapus data buku.

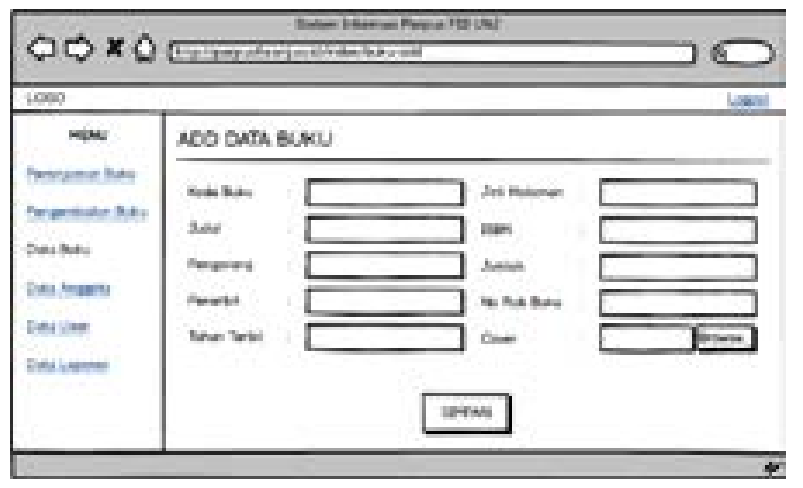

Gambar 17 Perancangan Halaman Tambah Data Buku

Berikut adalah halaman tambah data yaitu tampilan halaman untuk menambah data bagi data buku, data anggota, dan data user. Halaman ini tampil ketika meng-klik tombol "+Add Data" pada halaman data buku, data anggota, dan data user. Peneliti menampilkan halaman tambah data pada data buku sebagai contoh, karena halaman tambah data buku pada dasarnya sama dengan tampilan halaman tambah data pada data anggota dan data user. Pada halaman tambah data buku terdapat form untuk menambah data buku. Form tersebut terdiri dari kolom teks kode buku, judul, pengarang, penerbit, tahun terbit, jumlah halaman, ISBN, jumlah, nomor rak buku, dan cover buku. Setiap kolom teks tersebut harus diisi untuk disimpan ke dalam database. Setelah semua diisi, pustakawan meng-klik tombol "SIMPAN" untuk menyimpan data.

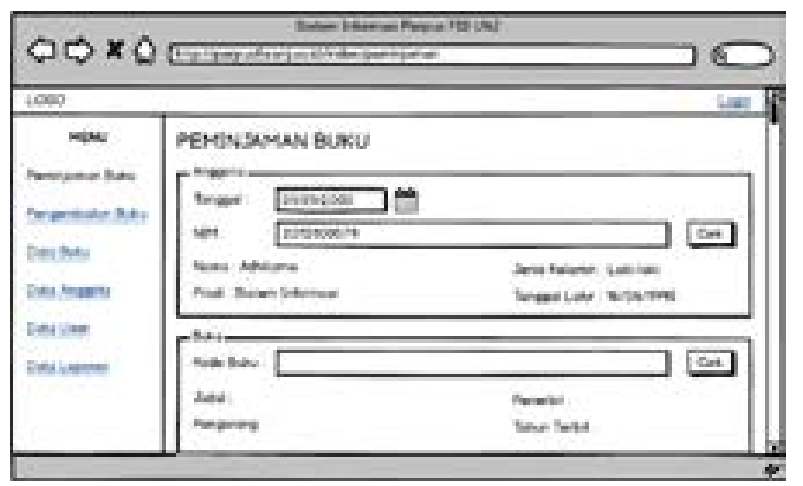

Gambar 18 Perancangan Halaman Peminjaman Buku
Gambar 18 merupakan perancangan halaman peminjaman, yaitu halaman yang dipakai untuk menambah data peminjaman baru. Untuk masuk ke halaman ini, pustakawan memilih menu "Peminjaman Buku". Pada form ini terdapat 2 bagian form yaitu bagian anggota dan buku. Pada bagian anggota terdapat kolom teks tanggal, dan NIM anggota. Pada kolom teks NIM anggota terdapat tombol "Cek" untuk Memeriksa apakah NIM yang dimasukkan terdaftar. Jika NIM tersebur terdaftar, maka akan tampil beberapa informasi dari anggota pemilik NIM tersebut antara lain, nama, program studi, jenis kelamin, dan tanggal lahir. Selanjutnya pada bagian buku, terdapat kolom teks kode buku dan tombol "Cek". Cara mengisinya juga sama seperti pada bagian anggota, pertama masukkan kode buku yang dipinjam kemudian klik tombol "Cek" dan akan tampil beberapa informasi buku tersebut antara lain, judul, pengarang, penerbit, dan tahun terbit. Jika informasi sudah tampil, kemudian klik tombol "Tambahkan" untuk menambahkan data buku ke dalam tabel daftar buku yang akan dipinjam. Buku yang dipinjam bisa lebih dari satu buku, maka jika ingin menambahkan buku satu lagi, ulangi dari proses memasukkan kode buku. Setelah selesai memasukkan daftar buku yang dipinjam, klik tombol "SIMPAN TRANSAKSI" untuk menyimpan data ke dalam data peminjaman.

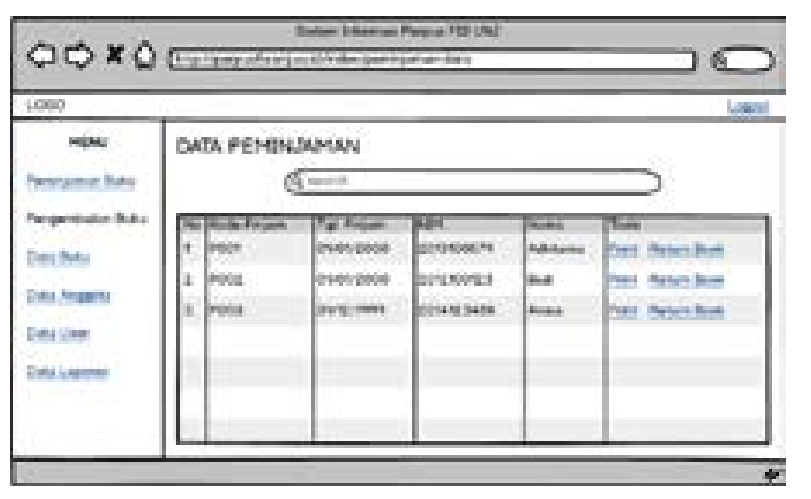

Gambar 19 Perancangan Halaman Pengembalian Buku

Halaman Pengembalian adalah halaman untuk melakukan transaksi pengembalian buku. Halaman ini tampil jika memilih menu "Pengembalian Buku". Halaman pengembalian dibagi menjadi dua yaitu halaman data peminjaman (Gambar 19) yang menampilkan data peminjaman yang berstatus masih dipinjam dan halaman form pengembalian buku (Gambar 20) yang tampil ketika meng-klik tools "Return Book".

Tampilan halaman form pengembalian buku pada Gambar 18 terdapat informasi nim, nama, dan program studi dari anggota (peminjam), tanggal pinjam, tanggal kembali, perhitungan denda jika 


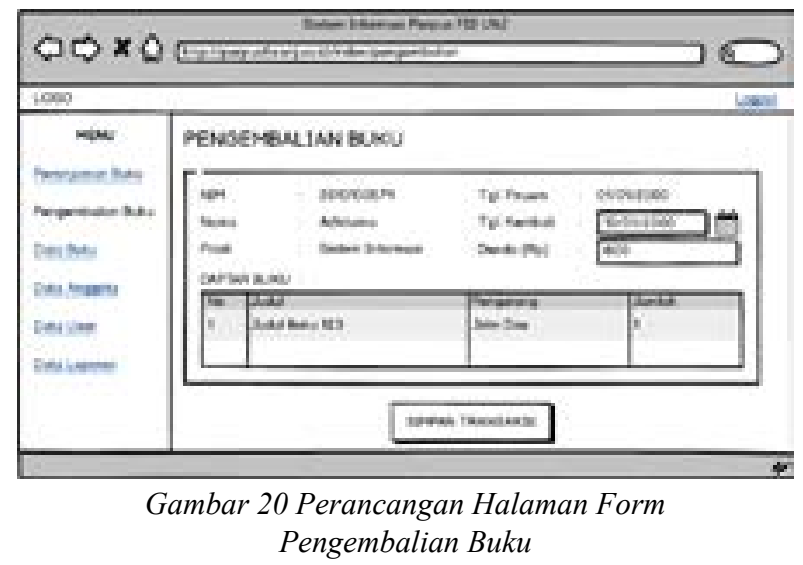

melewati batas waktu peminjaman, serta tabel daftar buku yang dipinjam. Jika informasi sudah sesuai, pustakawan meng-klik tombol "SIMPAN TRANSAKSI" untuk menyimpan data pengembalian ke dalam database.

\section{Pengkodean}

Setelah melakukan perancangan-perancangan, peneliti melanjutkan ke tahap pengkodean sistem. Pada tahap ini, peneliti melakukan pengkodean dengan bahasa pemrograman PHP dan HTML menggunakan perangkat lunak Adobe Dreamweaver CS6 serta pembangunan basis data menggunakan MySQL. Kemudian peneliti melanjutkan pada tahap pengujian sistem.

\section{Pengujian Sistem}

Pengujian sistem adalah tahapan dalam membangun sistem informasi dengan tujuan untuk mengetahui kelayakan sistem informasi yang telah dibangun, Hasil pengujian didapat berdasarkan dilakukannya pengujian sistem kepada pengguna sistem (user) yaitu pustakawan berdasarkan fungsifungsi dari sistem informasi Perpustakaan Fakultas Ilmu Sosial Universitas Negeri Jakarta yang telah dibuat peneliti. Hasil pengujian dimana menu uji merupakan menu didalam sistem yang diuji, kemudian hasil yang diharapkan adalah hasil yang tampil sesuai harapan peneliti ketika kasus uji dijalankan, dan hasil uji adalah peryataan yang dinyatakan oleh penguji dari hasil pengujian kasus apakah sesuai dengan hasil yang diharapkan atau tidak.

\section{SIMPULAN}

Pada penelitian ini dapat dihasilkan sistem informasi Perpustakaan Fakultas Ilmu Sosial (FIS) Universitas Negeri Jakarta (UNJ) berbasis web. Pengembangan sistem yang digunakan yaitu System Development Life Cycle (SDLC) model Waterfall.
Pada sistem informasi ini sebelumnya dilakukan proses perancangan yang dibagi menjadi tiga yaitu, perancangan sistem menggunakan Unified Modelling Language (UML), perancangan basis data pada level konsep, level logic, dan level fisik, kemudian yang ketiga perancangan antarmuka. Setelah melakukan proses perancangan, peneliti melakukan pengkodean dengan bahasa pemrograman PHP dan HTML. Sistem informasi Perpustakaan FIS UNJ dapat berfungsi sesuai dengan harapan peneliti saat dilakukan pengujian sistem. Pengujian sistem informasi ini dilakukan oleh pustakawan Perpustakaan FIS UNJ sebagai user dari sistem dengan pengujian blackbox. Pada hasil pengujian dapat disimpulkan bahwa sistem sudah dapat berfungsi sesuai dengan hasil yang diharapkan.

\section{DAFTAR PUSTAKA}

[1] T. Sutabri, Sistem Informasi Manajemen, Yogyakarta: Andi, 2005, hlm. 7-42.

[2] A. Mulyanto, Sistem Informasi Konsep dan Aplikasi, Yogyakarta: Pustaka Pelajar, 2009, hlm. 15.

[3] S. N. Sutarno., Perpustakaan dan Masyarakat, Jakarta: Sagung Seto, 2006, hlm. 11-12.

[4] E. Budiarti, "Sistem Informasi Pada Perpustakaan," 27 Maret 2014. [Online]. Available: https://erlisbudiarti. wordpress.com/2014/03/27/537/comment-page-1. [Accessed 14 Januari 2017].

[5] Y. Kustiyahningsih \& D. R. Anamisa, Pemrograman Basis Data Berbasis Web Menggunakan PHP \& MySQL, Yogyakarta: Graha Ilmu, 2011, hlm. 4.

[6] Kusrini, Strategi Perancangan dan Pengelolaan Basis Data, Yogyakarta: Andi, 2007, hlm. 2.

[7] A. N. Aditya, Jago PHP \& MySQL Dalam Hitungan Menit, Jakarta: Dunia Komputer, 2011, hlm. 16.

[8] R. A. Sukamto \& M. Shalahuddin, Rekayasa Perangkat Lunak: Terstruktur dan Berorientasi Objek, Bandung: Informatika, 2016, hlm. 44-163.

[9] V. Yasin, Rekayasa Perangkat Lunak Berorientasi Objek, Jakarta: Mitra Wacana Media, 2012, hlm. 276.

[10] F. Meilia, J. N. Mutaqin \& T. Pujadi, "Diagram Swimlane,” Binus University, 30 April 2014. [Online]. Available: http://sis.binus.ac.id/2014/04/30/diagramswimlane/. [Accessed 6 April 2017].

[11] I. Hooda \& R. S. Chhillar, "Software Test Process, Testing Types and Techniques," International Journal of Computer Applications, New York, vol. 111, no. 13, hlm. 12, 2015.

[12] A. Kadir, Pengenalan Sistem Informasi Edisi Revisi, 
Yogyakarta: Andi, 2014, hlm. 344.

[13] D. Nurdiansyah, "SDLC: Pengertian Waterfall Model | Keuntungan - Kelemahan," 1 Maret 2016. [Online]. Available: http://www.dhan.web.id/2016/03/sdlcpengertian-waterfall-model.html. [Accessed 3 Januari 2017]. 